\title{
BENTUK SAPAAN PRONOMINA PERSONA BAHASA TETUN DIALEK FEHAN
}

\section{ADDRESS FORM OF PRONOMINA PERSONA IN TETUN LANGUAGE FEHAN DIALECT}

\author{
${ }^{1}$ Kristofel Bere Nahak, ${ }^{2}$ Abdulrahman R. A.P. Dapubeang \\ ${ }^{1,2}$ Universitas Timor \\ berekristofe1@unimor.ac.id, ${ }^{2}$ armandapubeang32@gmail.com
}

\begin{abstract}
Abstrak
Penelitian ini bertujuan untuk mengetahui bentuk sapaan berdasarkan bentuk pronomina persona yang ada dalam bahasa Tetun dialek Fehan. Penelitian ini merupakan penelitian kualitatif dengan menggunakan teknik deskriptif. Pengumpulan data dilakukan dengan metode simak yang meliputi teknik sadap, libatcakap, simak bebas libat cakap, rekam, dan catat. Penelitian ini fokus pada pronomina persona yang digunakan sehari-hari oleh masyarakat Fehan. Penelitian ini dilakukan di Desa Kletek, Kecamatan Malaka Tengah, Kabupaten Malaka, Provinsi Nusa Tenggara Timur. Hasil penelitian menunjukkan bentuk pronomina persona bahasa Tetun dipengaruhi oleh tiga parameter yaitu; (1) usia, (2) status sosial, (3) Keakraban. Usia memiliki beberapa variabel yang mempengaruhi suatu bentuk sapaan pronomina persona, diantaranya bentuk hormat, keakraban, kerabat dekat dan bukan kerabat dekat. Status sosial memiliki dua faktor yang mempengaruhi suatu bentuk sapaan pronomina bahasa Tetun dialek Fehan, diantaranya variabel tingkat kekayaan dan profesi tertentu. Istilah yang digunakan oleh masyarakat Fehan penutur bahasa Tetun yaitu tata krama bakneter (penghormatan) dan hafolin (penghargaan) yang merupakan ciri khas dari masyarakat Fehan kepada mitra tutur yang memiliki status sosial yang tinggi dalam nilai sosial budaya masyaraka Fehan. Keakraban memiliki dua faktor yang mempengaruhi bentuk sapaan pronomina persona bahasa Tetun diantaranya faktor kekerabatan dan faktor usia. bentuk sapaan kmaluk dan belu merupakan sapaan keakraban dan bukan kerabat dekat sebagai ciri khas masyarakat Fehan kepada teman sebayanya yang memiliki profesi, hobi dan usia yang sama
\end{abstract}

Kata Kunci: bentuk sapaan, pronomina persona, bahasa Tetun, dialek Fehan

\begin{abstract}
This research aims to describe the address form based on personal pronouns form in Tetun language Feban dialect. This study is a qualitative study using a descriptive technique. The observation method that was used as basic techniques was tapping techniques and the advanced techniques were involved conversation observation technique, noting technique, and recording technique. This research focuses on personal pronouns used daily by Fehan society. This research was conducted in Kletek village, central Malaka District, Malaka Regency, East Nusa Tenggara province. The results showed the form of personal pronouns of Tetun language influenced by three parameters namely; (1) age, (2) social status, (3) intimacy. Age has several variables that affect an address form of personal pronoun including the form of respect (hakneter), appreciation ( hafolin), close relatives and not close relatives. Social Status has two factors That affect an address form of personal pronouns of Tetun language Fehan society dialect including variable levels of wealth and special professions. The term used by the Fehan in Tetun speakers is the respect (bakneter) and appreciation (bafolin) which is the characteristic of Fehan society to a speech partner with high social status in Socio-cultural value of Fehan society. Intimacy, two factors affects the address form of personal pronouns of Tetun language including kinship
\end{abstract}


and age factor. Address form of kmaluk and belu represents the address of intimacy and not a close relative as the identity of Fehan society to his close friend who has the same profession, hobby, and age

Keywords: address form, personal pronouns, Tetun language, Fehan dialect

\section{PENDAHULUAN}

Kata sapaan (address-term) merupakan bagian penting yang menjadi unsur pembangun suatu interaksi antarmanusia dalam suatu masyarakat bahasa. kata sapaan seringkali digunakan baik di awal, di tengah, maupun di akhir suatu wacana (discourse) dalam bahasa apapun.

Sistem sapaan dalam bahasa Indonesia tidak serumit bila dibandingkan dengan sistem sapaan pada bahasa-bahasa daerah yang kebanyakan menganut sistem stratifikasi sosial tertentu seperti bahasa Bali, bahasa Jawa, dan bahasa-bahasa daerah yang lainnya. Namun, karena para penutur bahasa Indonesia sangat dipengaruhi oleh budaya etniknya ketika berinteraksi dengan para penutur lain yang berasal dari etnis yang sama atau berbeda, sistem sapaan yang digunakanpun banyak dipengaruhi oleh budaya etnis tersebut. Seperti di Indonesia, sistem sapaan yang digunakan sangat kental oleh pengaruh etnisnya. Salah satu bahasa yang mengenal sistem sapaan tersebut adalah bahasa Tetun. Bahasa Tetun merupakan bahasa resmi yang digunakan secara mayoritas oleh masyarakat di Negara Timor Leste dan juga digunakan oleh masyarakat di Kabupaten Belu dan Kabupaten Malaka di Provinsi Nusa Tenggara Timur, Indonesia. Adapun bahasa Tetun yang digunakan di Kabupaten Belu dan Malaka disebut bahasa Tetun Terik. Bahasa Tetun Terik memiliki dua dialek; pertama, bahasa Tetun Terik dialek Fehan yang sering disebut Tetun Fehan. Kedua, bahasa Tetun Terik dialek Foho yang sering disebut Tetun Foho. Bahasa Tetun dialek Fehan merupakan salah satu dialek bahasa Tetun Terik yang digunakan masyarakat Kabupaten Malaka Provinsi Nusa Tenggara Timur. Salah satu fungsi bahasa Tetun Fehan yang sering digunakan masyarakat tuturnya dalam berkomunikasi adalah bentuk sapaan.

Bagi masyarakat penutur bahasa Tetun Fehan, sistem sapaan harus didasarkan pada beberapa pertimbangan. Sebagaimana yang dikemukakan oleh Wardaugh (1998:267) yang memaparkan tentang hal-hal yang menjadi pertimbangan dalam sistem sapaan sebagai berikut: "if we look at what is involved in addressing another, it seems that a variety of social factors usually governs our choice of terms: the particular occations; the social status or rank of the other; sex, age, family relationship, occupational hierarchy, transactional status, races, or degree of intimacy "ketika menyapa seseorang sangat dipengaruhi oleh banyak faktor sosial yang mengharuskan memilih kata sapaan yang tepat. Faktor-faktor sosial tersebut, antara lain kesempatan tertentu, status sosial, jenis kelamin, usia, hubungan keluarga, pekerjaan, status transaksi, ras, atau tingkat keintiman". Pertimbangan-pertimbangan dalam penggunaan bentuk sapaan tersebut sangat dipengaruhi oleh nilai-nilai budaya masyakarat penutur bahasa Tetun Fehan karena menentukan tingkat keramahan, kesopanan, keakraban, penghormatan, dan penghargaan dalam kehidupan sehari-hari. Istilah hakneter (penghormatan) dan hafolin (penghargaan) merupakan salah satu ciri khas dari masyarakat Fehan penutur bahasa Tetun dalam berkomunikasi. Oleh sebab itu, penggunaan bentuk sapaan harus dilakukan secara tepat. Kesalahan dalam penggunaan bentuk sapaan dapat menyebabkan kekeliruan dalam piranti perilaku sosial masyarakat. 
Brown dan Gilman (1960) menyatakan bahwa sistem sapaan merupakan sebuah sistem yang memiliki subsitem-subsistem atau unsur-unsur seperti pronomina persona, nama diri, gelar, sapaan kekerabatan, dan lain-lain. Istilah sapaan itu dipopulerkan oleh Brown dan Gilman (1960) dengan meneliti sejumlah sapaan pada bahasa-bahasa di Eropa seperti bahasa Perancis, Jerman, Spanyol, dan bahasa Inggris. Brown dan Gilman menemukan bahwa pemilihan kata ganti orang kedua yang digunakan pembicara kepada lawan bicaranya dipengaruhi oleh dua faktor yaitu kekuasaan (power) dan solidaritas (solidarity) (Fasol, 1994:3). Adanya kekuasaan serta solidaritas di antara penutur dan mitra tutur memunculkan dua bentuk kata ganti orang kedua yaitu vos selanjutnya disebut $\mathrm{V}$, digunakan untuk menyapa mitra tutur yang kedudukannya dianggap lebih tinggi dibandingkan penutur. Selanjutnya tu disebut $\mathrm{T}$, digunakan untuk menyapa mitra tutur yang kedudukannya dianggap lebih rendah daripada penutur. Berdasarkan bentuknya, sistem sapaan dikategorikan menjadi lima kategori (Brown dan Gilman 1960; Braun, 1988:16, 46; dan Hudson, 1995:169-170) di antaranya: (1) personal prounoun seperti: I, you dan He/she (2) Title seperti Sir, Madam, Mr, Mrs, Dr, dan Prof (3) proper name seperti Mr. Smith atau Jhon Smith (4) kinship terms seperti Father, Mother, Brother, Sister, Uncle dan Aunt (5) honorific terms seperti Excellency

Pronomina persona adalah pronomina yang dapat dipakai untuk mengacu pada orang (Alwi, dkk., 2003: 249). Pronomina persona dapat mengacu pada diri sendiri (pronomina persona pertama), mengacu pada orang yang diajak bicara (pronomina persona kedua), atau mengacu pada orang yang dibicarakan (pronomina persona ketiga). Di antara pronomina itu, ada yang mengacu pada jumlah satu atau lebih dari satu. Ada bentuk yang bersifat inklusif dan ada yang bersifat ekslusif, seperti yang terdapat dalam tabel di bawah ini.

Tabel 1. Pronomina Persona bahasa Tetun dialek Fehan

\begin{tabular}{cccc}
\hline \multicolumn{2}{c}{ Pronomina Persona Bahasa Tetun Dialek Fehan } \\
\cline { 2 - 3 } Penutur & Singular & \multicolumn{2}{c}{ Plural } \\
\cline { 3 - 4 } & & Inklusif & Eksklusif \\
\hline pertama & bau & ami & ita \\
\hline Kedua & o, ita bot, na'i & \multicolumn{2}{c}{ emi } \\
\hline Ketiga & nia & \multicolumn{2}{c}{ sia } \\
\hline
\end{tabular}

Hubungan sosial antarmanusia atau tata krama dalam kehidupan bermasyarakat menuntut adanya aturan yang serasi dengan martabat masing-masing. Pada umumnya ada tiga parameter yang dipakai sebagai ukuran: (1) umur, (2) status sosial, dan (3) keakraban (Alwi dkk., 2003: 250). Secara budaya orang yang lebih muda diharapkan lebih menunjukkan rasa hormat kepada orang yang lebih tua. Sebaliknya, orang yang lebih tua diharapkan pula menunjukkan tenggang rasa terhadap yang lebih muda tersebut. Hal ini akan berpengaruh pada penggunaan pronomina seseorang. Status sosial ikut pula mempengaruhi pemakaian pronomina. Seorang pimpinan bisa menggunakan pronomina kamu apabila berbicara dengan bawahannya. Sebaliknya, ia akan memakai kata Saudara atau Bapak jika berbicara dengan koleganya. Keakraban dapat menyilang garis pemisah umur dan status sosial dalam penggunaan pronomina persona meskipun kadang-kadang hanya dalam situasi-situasi 
tertentu. Dua orang yang sejak kecil telah bersahabat dapat saja tetap memakai pronomina kamu meskipun yang satu telah memiliki status sosial yang tinggi.

Penelitian yang dilakukan oleh Puspa Ruriana (2018) tentang sistem Pronomina persona dalam bahasa Blambangan ada tiga, yaitu pronomina persona pertama, pronomina persona kedua, dan pronomina persona ketiga. Selain ketiga bentuk pronomina tersebut ditemukan pula bentuk- bentuk lain sebagai pengganti pronomina persona dalam bahasa Blambangan, seperti dieksis, kata benda, kata benda dan keterangan waktu, serta pengulangan kata benda dan keterangan waktu

Penelitian yang dilakukan oleh I Nyoman Suwija (2018) tentang sistem sapaan bahasa Bali menurut hubungan kekerabatan, yang mengkaji hubungan kekerabatan bahasa Bali yang meliputi faktor: (1) usia partisipan, (2) kedudukan dalam keluarga, (3) jenis kelamin, dan (4) hubungan keluarga langsung. Bentuk sapaan bahasa Bali tergantung situasi dan status sosial para partisipan. Artinya, pada keluarga wangsa jaba atau orang kebanyakan berbentuk basa andap atau bahasa tingkatan biasa, sedangkan untuk keluarga triwangsa atau bangsawan menggunakan kata-kata bahasa Bali yang halus atau kruna alus.

Hasil penelitian sebelumnya dijadikan pedoman sebagai bahan pelengkap dan pembanding dalam mendeskripsikan berbagai unsur yang bergayutan dengan pronomina persona Bahasa Tetun dialek Fehan. Berdasarkan latar belakang penelitian ini, ada beberapa masalah yang akan dikaji menggunakan parameter usia, status sosial dan keakraban dalam pronomina persona bahasa Tetun dialek Fehan. Sebagai contoh dalam kehidupan sehari-hari, seorang anak muda yang memiliki status sosial yang tinggi seperti kepala desa, karena memiliki kedudukan yang tinggi dalam nilai sosial budaya masyarakat Tetun Fehan maka, penutur usia tua sekalipun akan menyapa dengan menggunakan bentuk sapaan ikatan kekerabatan 'ama' dan nama profesi 'desa' seperti ama desa (bapak desa). Contoh yang lain yang menjadi ciri khas masyarakat Fehan adalah bentuk sapaan 'kmaluk dan belu' yang merupakan sapaan keakraban yang bukan kerabat dekat yang memiliki profesi, hobi, dan usia yang sama. Berdasarkan uraian tersebut, dipandang penting dan perlu untuk dilakukan penelitian tenang "Bentuk Sapaan Pronomina Persona Bahasa Tetun Dialek Fehan".

\section{METODE}

Metode penelitian merupakan alat, prosedur dan teknik yang dipilih dalam melaksanakan penelitian (dalam mengumpulkan data). Metode penelitian bahasa berhubungan erat dengan tujuan penelitian bahasa. penelitian bahasa bertujuan mengumpulkan dan mengkaji data, serta mempelajari fenomena-fenomena kebahasaan (Djajasudarma, 2010: 4). Metode yang digunakan dalam penelitian ini adalah metode kualitatif. Penerapan metode kualitatif sejalan dengan pernyataan Djajasudarma (2006:10) bahwa metode kualitatif merupakan prosedur yang menghasilkan data secara deskriptif, baik tulis maupun lisan yang berkembang atau berada di masyarakat.

Metode pengumpulan data yang digunakan adalah metode simak. Hal ini sejalan dengan pendapat Sudaryanto (dalam Astriana: 2013: 6) bahwa dalam metode simak digunakan teknik dasar yang meliputi teknik sadap, libatcakap, simak bebas libat cakap, rekam, dan catat. Penelitian ini dilakukan di Desa Kletek, Kecamatan Malaka Tengah, 
Kabupaten Malaka, Provinsi Nusa Tenggara Timur yang penduduknya menggunakan dialek Tetun Fehan. Selanjutnya Sudaryono (dalam Mahsun, 2006:104) analisis data amenggunakan metode refleksi, intropektif, yaitu upaya melibatkan atau memanfaatkan sepenuhnya, optimal, peran peneliti sebagai penutur bahasa tanpa melebur-lenyapkan peran penelitian itu.

\section{HASIL DAN PEMBAHASAN}

Dalam bahasa Tetun dialek Fehan, terdapat tiga jenis pronomina yang biasa digunakan oleh masyarakat Fehan sebagai bentuk sapaan, yakni (1) pronomina persona pertama. Dalam bahasa Tetun dialek Fehan, pronomina persona pertama dibedakan menjadi dua yaitu pronomina persona pertama tunggal hau dan pronomina persona pertama jamak inklusif ami, dan eksklusif ita. (2) Pronomina persona kedua. Dalam bahasa Tetun dialek Fehan, pronomina persona kedua merupakan kata ganti yang digunakan untuk menunjuk pada orang kedua (mitra tutur). terdapat dua bentuk pronomina persona kedua yaitu pronomina persona kedua tunggal $o$, ita bot, na'i dan pronomina persona kedua jamak emi. (3) pronomina persona ketiga. Pronomina persona ketiga bahasa Tetun dialek Fehan dibagi menjadi dua yaitu pronomina persona ketiga tunggal nia digunakan oleh penutur dan mitra tutur dalam suatu peristiwa bahasa sebagai acuan yang merujuk pada orang ketiga tunggal (dia), sedangkan pronomina persona ketiga jamak sia digunakan oleh para penutur bahasa Tetun dialek Fehan dalam suatu peristiwa bahasa sebagai acuan yang merujuk pada orang ketiga jamak (mereka).

Dalam pembahasan pronomina persona persona bahasa Tetun dialek Fehan, penulis menggunakan tiga parameter yang dipakai sebagai ukuran: (1) usia, (2) status sosial, dan (3) keakraban (Alwi, dkk., 2003: 250).

\section{Usia}

Dalam bahasa Tetun dialek Fehan, usia merupakan salah satu bentuk variabel yang sangat mempengaruhi suatu peristiwa tutur antara penutur dengan mitra tuturnya, dimana masyarakat Fehan di Desa Kletek masih memegang teguh adat-istiadat dan tradisi dimana penutur usia muda sudah semestinya menghormati penutur yang berusia dewasa ataupun orang yang lebih tua.

a) Pronomina persona pertama bahasa Tetun dialek Fehan

Masyarakat Fehan di Desa Kletek, penutur usia dewasa dan usia tua dalam suatu suatu peristiwa bahasa menggunakan bentuk istilah kekerabatan bei, (kakek./nenek) ama (bapak), ina (ibu), tuak (paman), baba (tante, )mau (kakak Laki-laki), bi (kakak perempuan) dengan mitra tuturnya yang berusia muda / berusia anak-anak sebagai bentuk akrab dan solidaritas kepada mitra tuturnya, yang merujuk pada dirinya sendiri (saya). Penggunaan istilah kekerabatan juga berlaku untuk bentuk jamak inklusif ami, dan eksklusif ita. Contoh ketika para penutur (tua dan muda) menggunakan istilah kekerabatan ama dan nama diri klau, kepada mitra tuturnya yang berusia muda sebagai bentuk akrab pengganti pronomina persona pertama jamak inklusif ami (kami). Sedangkan bentuk jamak eksklusif ita tidak mengalami perubahan. 
Selanjutnya masyarakat Fehan usia lebih muda atau anak-anak menggunakan bentuk nama diri (nama diri Fehan: abuk, klau, rika atau nama diri baptis: albertus, albertina, marianus, maria atau nama diri hiponimi: metan, mutin, modok, meak) dengan mitra tutur usia dewasa atau usia tua sebagai bentuk akrab dan hormat kepada mitra tuturnya yang merujuk pada diri sendiri sebagai pengganti bentuk sapaan hau (saya)

b) Pronomina persona kedua bahasa Tetun dialek Fehan

Bentuk $o$, merupakan bentuk sapaan pronomina persona kedua tunggal bahasa Tetun dialek Fehan yang umumnya digunakan oleh semua kalangan usia, akan tetapi bentuk o tersebut merupakan bentuk sapaan yang kasar, dimana masyarakat Fehan hanya menggunakan bentuk $o$ tersebut oleh penutur yang berusia dewasa dan usia tua sebagai bentuk akrab dalam suatu peristiwa bahasa kepada mitra tuturnya yang berusia muda/ anak-anak. Akan tetapi kebanyak masyarakat Fehan usia dewasa dan usia tua saat ini, menggunakan bentuk sapaan nama diri fehan (klau) atau nama diri baptis (albert) atau nama diri hiponimi (metan, mutin, modok, meak) sebagai bentuk akrab dan bentuk solidaritas kepada mitra tuturnya yang memiliki hubungan kekerabatan. disisi yang lain penggunaan bentuk sapaan istilah kekerabatan ali, oa, oa bei, oleh usia dewasa dan usia tua kepada mitra tuturnya sebagai bentuk santun kepada mitra tutur yang berusia muda, anak, anak, atau sebagai cucu yang bukan kerabat dekat. Selanjutnya bentuk sapaan istilah kekerabatan bei, (kakek./nenek) ama (bapak), ina (ibu), tuak (paman), baba (tante, )mau (kakak. Laki-laki), bi (kakak perempuan) digunakan oleh penutur usia muda dan usia anak-anak kepada mitra tutur usia dewasa dan tua yang bukan kerabat dekat sebagai bentuk hormat , dan penggunaan bentuk sapaan istilah kekerabatan dan nama diri fehan atau nama diri baptis (baba rika, ina martha) sebagai bentuk sapaan akrab dan memiliki hubungan kekerabatan.

Bentuk ita bot, merupakan bentuk sapaan pronomina persona kedua tunggal bahasa Tetun dialek Fehan yang digunakan oleh penutur yang usianya sama dengan mitra tutur. masyarakat penutur bahasa Tetun dialek Fehan di Desa kletek, umumnya menggunakan bentuk ita bot sebagai bentuk sapaan yang hormat yang ditujukan kepada mitra tutur dalam suatu peristiwa tutur, dimana penutur dan mitra tuturnya tidak saling mengenal atau tidak memiliki hubungan kekerabatan

Bentuk na'i merupakan bentuk sapaan pronomina persona kedua tunggal bahasa Tetun dialek Fehan yang digunakan oleh penutur yang berusia tua kepada mitra tuturnya yang berusia lebih muda sebagai sapaan penghargaan. Masyarakat Fehan dahulu kala, biasanya menggunakan bentuk sapaan na"i kepada orang yang memiliki kedudukan tinggi seperti keturunan bangsawan. Akan tetapi seiring dengan perkembangan zaman, saat ini bentuk sapaan na'i tersebut akan lebih familiar digunakan oleh penutur berusia dewasa dan penutur berusia tua kepada mitra tuturnya yang usianya masih muda yang memiliki kedudukan atau status sosial yang tinggi dalam masyarakat (profesi tertentu) di pemerintahan, agama seperti guru, dokter, kepala desa, pastor, dan ustad,dll. Contoh na'i desa, na'i dokter, na'i lulik (pastor) dll. 
Masyarakat Fehan penutur bahasa Tetun mengenal bentuk sapaan kmaluk dan belu. Bentuk sapaan kmaluk atau belu tersebut digunakan oleh penutur kepada mitra tuturnya yang memiliki hubungan keakraban, memiliki usia yang sama, dan kekerabatan yang jauh (tidak ada hubungan keluarga). Sapaan tersebut biasanya lebih banyak digunakan oleh remaja dan tidak menutup kemungkinan banyak masyarakat Fehan penutur bahasa Tetun usia dewasa dan usia tua juga menggunakan bentuk sapaan kmaluk dan belu kepada mitra tuturnya. bentuk sapaan kmaluk dan belu merupakan sapaan unisex

Penutur usia muda dan usia anak-anak menggunakan bentuk sapaan istilah kekerabatan dan nama diri (fehan, baptis, profesi) sebagai bentuk hormat, akrab dan memiliki hubungan kekerabatan kepada mitra tuturnya yang berusia dewasa dan usia tua sebagai contoh (ama desa dan bei camat) sebagai acuan kepada orang kedua jamak emi. Sedangkan penutur usia dewasa dan usia tua menggunakan bentuk sapaan nama diri Fehan (rika, abuk) atau nama diri baptis (martina, maximus) maupun nama diri hiponimi: metan, mutin, modok, meak sebagai bentuk akrab, selanjutnya menggunakan bentuk sapaan istilah kekerbatan ali, oa, oa bei sebagai bentuk santun bukan kerabat dekat kepada mitra tutur yang usia muda dan usia anak-anak. Bentuk sapaan emi tersebut merupakan sapaan unisex, dimana mitra tutur yang merupakan lebih dari satu orang tersebut bisa laki-laki dan perempuan.

c) Pronomina persona ketiga bahasa Tetun dialek Fehan

Jika dikaji lebih dalam lagi, bentuk sapaan nia oleh masyarakat penutur bahasa Tetun dialek Fehan merupakan sapaan yang kasar, jika ditujukan atau merujuk pada orang usia dewasa maupun usia tua, sehingga masyarakat Fehan usia dewasa dan usia tua menggunakan sapaan istilah kekerabatan (ali, oa, oa bein) dan nama dirifehan (abuk, seran) atau nama diri baptis (maria) maupun nama diri hiponimi (metan, mutin, modok, meak) sebagai bentuk akrap dan memiliki hubungan kekerabatan yang merujuk kepada orang yang dibicarakan yang berusia muda. Contoh ketika para petutur melakukan suatu peristiwa tutur yang merujuk kepada orang yang dibicarakan sebagai pengganti bentuk nia yang lebih akrab, maka para petutur tersebut akan menggunakan sapaan oa abuk, ali seran, oa bei maria. Bentu sapaan tersebut sapaan tersebut juga berlaku untuk bentuk jamak sia sebagai contoh ali abuk no oa maria (adik abuk dan anak maria)

Penggunaan bentuk sapaan istilah kekerabatan dan nama diri fehan, nama diri baptis, dan nama diri profesi maupun nama diri hiponimi (metan, mutin, modok, meak) juga merupakan salah satu bentuk sapaan akrab dimana para petutur sudah mengenal dengan baik orang-orang yang dicarakan. Apabila masyarakat Fehan penutur bahasa Tetun hanya menggunakan bentuk sapaan istilah kekerabatan tanpa adanya nama diri (fehan/Baptis/gelar) merujuk kepada orang-orang yang dibicarakan artinya para petutur tersebut belum mengenal dengan akrab orang yang dibicarakan tersebut, sehingga masyarakat Fehan hanya menggunakan pemarkah istilah kekerabatan bei, (kakek. nenek) ama (bapak), ina (ibu), tuak (paman), baba (tante, )mau (kakak Laki-laki), bi (kakakperempuan) ali (adik), oa (anak), oa bein (cucu) sebagai bentuk hormat kepada orang-orang yang 
dibicarakan yang merujuk kepada usia orang-orang yang menjadi obyek pembicaraan para petutur.

\section{Status Sosial}

Masyarakat penutur bahasa Tetun dialek Fehan merupakan masyarakat yang sangat menghargai sopan-santun sebagai tata krama dalam suatu peristiwa bahasa. Tata krama hakneter (penghormatan) dan hafolin (penghargaan) merupakan salah satu ciri khas dari masyarakat Fehan penutur bahasa Tetun. Sejak dahulu, masyarakat Fehan dikenal dengan keramahannya, kesopanannya, serta adat istiadat yang dijunjung tinggi. Penulis juga merupakan penutur asli bahasa Tetun dialek Fehan yang akan mengkaji sistem sapaan bahasa tetun dialek Fehan berdasarkan variabel status sosial. Bentuk sapaan pronomina persona dikaji berdasarkan dua faktor yang mempengaruhi status sosial masyarakat penutur bahasa Tetun dialek Fehan yaitu tingkat kekayaan dan pekerjaan (profesi). Berikut merupakan bentuk sapaan pronomina persona bahasa Tetun dialek Fehan dikaji berdasarkan status sosial para penuturnya.

a) Pronomina persona pertama bahasa Tetun dialek Fehan

Sama halnya seperti pronomina persona pertama yang dikaji berdasarkan tingkat usia para penuturnya, begitu juga dengan pronomina persona pertama yang dikaji berdasarkan status sosial. Maka status sosial penutur dan mitra tuturnya memiliki peran yang penting untuk mengukur suatu bentuk sapaan tersebut sebagai bentuk hakneter (penghormatan) atau bentuk bafolin (penghargaan) Penutur yang memiliki tingkat kekayaan yang lebih dari mitra tuturnya, akan menggunakan bentuk sapaan istilah kekerabatan kekerabatan bei (kakek/nenek), ama (bapak), ina (ibu), mau (kakak laki-laki), bi (kakak perempuan) ali (adik), oa (anak) yang merujuk pada dirinya sendiri sebagai bentuk penghormatan kepada mitra tuturnya, selanjutnya penutur yang memiliki tingkat kekayaan yang lebih rendah dari mitra tuturnya, dalam suatu peristiwa tutur juga menggunakan bentuk sapaan istilah kekerabatan bei (kakek. nenek), ama (bapak), ina (ibu), mau (kakak laki-laki), bi (kakak perempuan) yang merujuk pada dirinya sendiri sebagai makna penghargaan kepada mitra tuturnya.

Masyarakat Fehan penutur bahasa Tetun mengenal beberapa pekerjaan sebagai profesi yang dipandang memiliki status sosial yang tinggi bahkan lebih terhormat seperti kepala desa, camat, kepala dinas, dokter, guru, dan pastor. Dalam suatu peristiwa bahasa penutur yang merupakan seorang kepala desa menggunakan bentuk sapaan istilah kekerabatan bei (kakek/nenek), ama (bapak), ina (ibu), man (kakak laki-laki), bi (kakak perempuan) ali (adik), oa (anak) ali (adik), oa (anak) yang merujuk pada dirinya sendiri sebagai makna penghormatan kepada mitra tuturnya. Sebaliknya penutur yang yang memiliki status sosial yang rendah menggunakan bentuk sapaan istilah kekerabatan bei (kakek.nenek), ama (bapak), ina (ibu), mau (kakak laki-laki), bi (kakak perempuan) oa (anak) ali (adik), oa (anak) yang merujuk pada dirinya sendiri sebagai makna penghargaan kepada mitra tuturnya yang memiliki status sosial yang tinggi 
b) Pronomina persona kedua bahasa Tetun dialek Fehan

Dalam bahasa Tetun dialek Fehan, terdapat dua jenis pronomina persona kedua, yaitu pronomina persona kedua tunggal $o$, ita bot, dan $n a^{\prime} i$, dan pronomina persona kedua jamak emi. Jika dikaji sesuai dengan tingkat kekayaan dan profesi antara penutur dan mitra tuturnya berdasarkan status sosial, maka figure para penutur bahasa tersebut memiliki peran yang penting untuk mengukur suatu bentuk sapaan tersebut sebagai makna hakneter (penghormatan) atau makna hafolin (penghargaan). Dalam suatu peristiwa bahasa, status sosial penutur yang memiliki tingkat kekayaan yang lebih dari mitra tuturnya atau penutur yang memiliki profesi tertentu sebagai kepala dinas, dokter, guru kepada mitra tuturnya menggunakan bentuk istilah kekerabatan bei (kakek/nenek), ama (bapak), ina (ibu), mau (kakak laki-laki), bi (kakak perempuan) oa (anak) ali (adik), oa (anak) yang merujuk kepada mitra tuturnya sebagai bentuk penghormatan (bakneter).

Sebagai contoh ketika seorang penutur bertemu dengan orang asing dari daerah lain, penutur tersebut belum mengenal nama, bahkan profesi mitra tuturnya tersebut, maka si penutur tetap akan menggunakan bentuk ita bot kepada mitra tuturnya sebagai makna penghargaan (hafolin) dalam artian hafolin disini karena semakin jauh jarak antara penutur dan mitra tuturnya maka makna penghargaan (bafolin) ini akan semakin tinggi nilainya. Selanjutnya ketika sorang penutur bertemu dengan seorang kepala desa yang memiliki status sosial tinggi di masyarakat Fehan, maka si penutur akan menggunakan sapaan bentuk na'i dan nama profesi sebagai makna penghormatan (hakneter) kepada mitra tuturnya yang berprofesi sebagai seorang kepala desa. Sebaliknya penutur yang yang memiliki status sosial yang rendah memilih menggunakan bentuk istilah kekerabatan bei (kakek/nenek), ama (bapak), ina (ibu), mau (kakak laki-laki), bi (kakak perempuan) oa (anak) ali (adik), oa (anak) yang merujuk kepada mitra tuturnya sebagai bentuk penghargaan (bafolin)

c) Pronomina persona ketiga bahasa Tetun dialek Fehan

Jika dikaji berdasarkan tingkat kekayaan dan profesi tertentu, masyarakat Fehan sangat berhati-hati untuk memilih bentuk sapaan yang tepat sebagai pengganti bentuk sapaan pronomina persona ketiga tunggal nia dan jamak sia. Figure orang ketiga tersebut apakah memiliki status yang tinggi atau profesi tertentu sehingga para penutur bahasa Tetun dialek Fehan harus berhati- hati dalam memilih bentuk sapaan. Artinya, para penutur bahasa memiliki memiliki peran yang penting untuk mengukur suatu bentuk sapaan tersebut sebagai bentuk hakneter (penghormatan) atau bentuk hafolin (penghargaan) yang merujuk kepada obyek pembicaraan atau orang yang dibicarakan. Sebagai contoh ketika para penutur bahasa Tetun sedang membahas tentang seseorang yang memiliki status sosial yang tinggi, yang memiliki profesi sebagai seorang kepala desa, maka para pentur tersebut menggunakan bentuk sapaan istilah kekerabatan bei (kakek/nenek), ama (bapak), ina (ibu), mau (kakak laki-laki), bi (kakak perempuan) ali (adik), oa (anak) dan nama profesi (kepala dinas, kepala desa, guru,dll) yang merujuk kepada orang dibicarakan (ama desa, bei kuru) sehingga bentuk sapaan tersebut memiliki makna penghormatan (bakneter), sebaliknya ketika para pentur bahasa Tetun membahas 
seseorang yang memiliki status sosial yang rendah, maka para penutur bahasa tersebut tetap menggunakan bentuk pronomina persona ketiga tunggal nia dan jamak sia.

\section{Keakraban}

Dalam bahasa Tetun dialek Fehan, ada beberapa dua faktor yang berpengaruh terhadap parameter keakraban, seperti faktor hubungan kekerabatan dan usia

a) Pronomina persona pertama bahasa Tetun dialek Fehan

Jika dilihat dari faktor hubungan kekerabatan (kerabat dekat), maka bentuk sapaan yang keakraban yang dituturkan oleh para penutur bahasa Tetun dialek Fehan kepada orang pertama tunggal hau, dan orang pertama jamak inklusif ami dan eksklusif ita tidak mengalami perubahan. Sedangkan dalam suatu peristiwa bahasa, para penutur bahasa tidak memiliki hubungan kerabat dekat, maka penutur akan menggunakan bentuk sapaan istilah kekerabatan bei (kakek/nenek), ama (bapak), ina (ibu), mau (kakak laki-laki), bi (kakak perempuan) ali (adik), oa (anak) yang merujuk pada dirinya sendiri sebagai acuan bentuk akrab dengan mitra tuturnya.

b) Pronomina persona kedua bahasa Tetun dialek Fehan

Dalam bahasa Tetun dialek Fehan, jika hubungan antarpenutur semakin akrab dan dekat maka, para penutur tetap menggunakan bentuk sapaan $o$ sebagai acuan yang merujuk kepada mitra tuturnya. sedangkan bentuk pronomina persona kedua tunggal ita bot, digunakan oleh penutur kepada mitra tuturnya dimana penutur dan mitra tuturnya tidak memiliki hubungan keakraban maupun hubungan kekerabatan sebagai acuan yang merujuk kepada mitra tuturnya sebagai bentuk sapaan penghormatan. Masyarakat di Desa Kletek berusia dewasa dan usia tua menggunakan bentuk sapaan na'i kepada mitra tuturnya yang berusia muda dan usia anak-anak yang memiliki hubungan keakraban dan kerabat dekat sebagai bentuk sapaan keakraban.

Emi merupakan pronomina persona kedua jamak bahasa Tetun dialek Fehan. Bentuk sapaan emi digunakan oleh penutur untuk menyapa mitra tuturnya yang memiliki hubungan keakraban dan kekerabatan dekat sebagai bentuk sapaan keakraban. Sebagai contoh seorang penutur akan memilih menggunakan bentuk sapaan ikatan kekerabatan bei (kakek/nenek), ama (bapak), ina (ibu), mau (kakak laki-laki), bi (kakak perempuan) ali (adik), oa (anak) dan nama profesi (desa, camat, guru, dokter, dll) dengan sebutan bei desa no bei camat (bapak desa dan bapak camat) kepada para mitra tuturnya sebagai acuan untuk mengganti bentuk sapaan pronomina persona kedua jamak emi.

Usia merupakan salah satu faktor yang mempengaruhi variabel keakraban. Dimana masyarakat Fehan mengenal bentuk sapaan kmaluk dan belu yang digunakan oleh penutur kepada mitra tuturnya yang memiliki hubungan keakraban, memiliki usia yang sama, dan kekerabatan yang jauh (tidak ada hubungan keluarga). Sapaan tersebut biasanya lebih banyak digunakan oleh remaja dan tidak menutup kemungkinan banyak masyarakat Fehan penutur bahasa Tetun usia dewasa dan usia tua menggunakan bentuk sapaan kmaluk dan belu tersebut kepada mitra tuturnya sebagai bentuk sapaan keakraban 
c) Proniomina persona ketiga bahasa Tetun dialek Fehan

Nia merupakan bentuk sapaan pronomina persona ketiga tunggal dan sia merupakan bentuk sapaan pronomina persona ketiga jamak bahasa Tetun dialek Fehan. Bentuk sapaan tunggal nia dan jamak sia tersebut tidak akan mengalami perubahan apabila para penutur memiliki hubungan keakraban dengan orang yang menjadi obyek pembicaraan sebagai acuan orang ketiga tunggal (dia) dan jamak (mereka). Selanjutnya, jika dikaji dari usia dan hubungan kerabat dekat orang ketiga tunggal nia dan jamak sia, maka para penutur lebih memilih menggunakan bentuk sitilah kekerabatan bei (kakek/nenek), ama (bapak), ina (ibu), tuak (paman), baba (tanta), man (kakak laki-laki), bi (kakak perempuan) ali (adik), oa (anak) dan nama diri fehan/babtis, sebagai acuan yang merujuk kepada orang ketiga tunggal (dia) dan jamak (mereka) Sebagai contoh bentuk tunggal tuak klau dan bentuk jamak (tuak klau dan baba lotu) dalam hal ini para penutur memiliki hubungan akrab dan hubungan kerabat dekat dengan orang ketiga tersebut.

\section{SIMPULAN}

Bentuk sapaan pronomina persona bahasa Tetun dialek Fehan sangat bervariasi. Hal tersebut disebabakan oleh tiga parameter yang dijadikan sebagai fondasi dasar dalam menganalisis bentuk sapaan pronomina persona, diantaranya (1) usia, (2) status sosial, dan (3) keakraban. Para meter usia memiliki beberapa variabel yang mempengaruhi suatu bentuk sapaan pronomina persona, diantaranya bentuk hormat, keakraban, kerabat dekat dan bukan kerabat dekat. Usia muda akan menggunakan bentuk sapaan, istilah kekerabatan dan nama profesi kepada mitra tuturnya yang berusia tua sebagai bentuk hormat, selanjutnya usia dewasa menggunakan bentuk sapaan nama diri fehan, nama diri baptis dan nama diri hiponimi kepada mitra tutur usia muda sebagai bentuk akrab dan solidaritas. Bentuk ita bot, merupakan bentuk sapaan pronomina persona kedua tunggal bahasa Tetun dialek Fehan yang digunakan oleh penutur yang usianya sama dengan mitra tutur. masyarakat Fehan umumnya menggunakan bentuk ita bot sebagai bentuk sapaan yang hormat yang ditujukan kepada mitra tutur dalam suatu peristiwa tutur, dimana penutur dan mitra tuturnya tidak saling mengenal atau tidak memiliki hubungan kekerabatan. Selanjutnya Bentuk na'i merupakan bentuk sapaan pronomina persona kedua tunggal bahasa Tetun dialek Fehan yang digunakan oleh penutur yang berusia tua kepada mitra tuturnya yang berusia lebih muda sebagai sapaan penghargaan.

Para meter Status sosial memiliki dua faktor yang mempengaruhi suatu bentuk sapaan bahasa Tetun dialek Fehan, diantaranya variabel tingkat kekayaan dan profesi tertentu. Ada istilah yang digunakan oleh masyarakat Fehan penutur bahasa Tetun yaitu Tata krama hakneter (penghormatan) dan hafolin (penghargaan) yang merupakan ciri khas masyarakat Fehan dalam berkomunikasi. Penggunaan bentuk sapaan oleh penutur yang memiliki status sosial yang tinggi kepada mitra tuturnya yang memiliki status sosial rendah menggunakan bentuk sapaan istilah kekerabatan sebagai rujukan untuk diri sendiri, mitra tuturnyanya, maupun orang yang dibicarakan sebagai pengganti pronomina persona pertama, kedua dan ketiga maka bentuk sapaan tersebut akan memiliki makna hafolin (penghargaan), sebaliknya penutur yang memiliki status sosial yang rendah menggunakan bentuk sapaan istilah 
kekerabatan dan nama profesi yang merujuk kepada diri sendiri, mitra tuturnyanya, maupun orang yang dibicarakan sebagai pengganti pronomina persona pertama, kedua dan ketiga maka bentuk sapaan tersebut akan memiliki makna hakneter (penghormatan)

Selanjutnya para meter keakraban. Ada dua faktor yang mempengaruhi bentuk sapaan pronomina persona bahasa Tetun diantaranya faktor kekerabatan dan faktor usia. faktor kekerabatan dekat ditemukan ketika seorang penutur menggunakan bentuk sapaan istilah kekerabatan dan nama diri fehan atau nama diri baptis maupun nama diri hiponimi kepada mitra tuturnya, sedangkan seorang penutur apabila hanya menggunakan sapaan istilah kekerabatan kepada mitra tuturnya maka, kedua penutur tersebut tidak memiliki hubungan kerabat dekat. Selanjutnya faktor usia juga mempengaruhi suatu bentuk tuturan tersebut lebih akrab atau tidak, bentuk sapaan kmaluk dan belu merupakan sapaan keakraban dan bukan kerabat dekat sebagai ciri khas masyarakat Fehan kepada teman sebayanya yang memiliki profesi dan hobi yang sama. semakin akrab hubungan antarpara penutur maka, tuturan tersebut akan semakin jauh makna kesantunannya, sebaliknya semakin jauh hubungan keakraban antarpenutur maka, tuturan tersebut akan semakin santun.

\section{DAFTAR PUSTAKA}

Alwi, Hasan, dkk. (2003). Tata Bahasa Baku Bahasa Indonesia. Edisi ketiga. Jakarta: Balai Pustaka.

Brown, Frederike. (1998). Term of Address Problems of Pattern and Usage in Various Languages and Cultures. New York: Mouton.

Brown R, W, and Gilman A. (1960). 'The Pronouns of Power and Solidarity'. Dalam J. A. Fishman (1970) Reading in Sociology of Language. Paris Mouton

Djajasudarma, Fatimah. (2010). Metode Linguistik: Ancangan Metode Penelitian dan Kajian. Jakarta: Refika Aditama

Mahsun, M.S. (2005). Metode Penelitian Babasa. Jakarta: Raja Grafindo Persada

Moleong, L. J. ( 2002). Metode Penelitian Kualitatif. Bandung: Remaja Rosdakarya

Nahak, K. B. (2012).Sistem Sapaan Bahasa Tetun dialek Fehan, Kajian Makna Penghormatan dan Kesantunan. Denpasar: Program Studi Linguistik, Program Pascasarjana Universitas Udayana

Nyoman, I. Suwija (2018). Sistem sapaan Bahasa Bali Menurut Hubungan Kekerabatan. Sosiohumaniora: Jurnal Ilmu-ilmu Sosial dan Humaniora Volume 20, No. 2, Juli 2018 Ruriana, Puspa (2018) Pronomina Persona dan Bentuk-Bentuk Lain Pengganti Pronomina Persona Dalam Bahasa Blambangan: Balai Bahasa Jawa Timur: Metalingua, Vol. 16 No. 2, Desember 2018:231-246

Sugiono. (2015)Metode Penelitian Kuantitatif, Kualitatif, dan R\&D. Bandung: Alfabeta. Sugiono. (2007). Memahami Penelitian Kualitatif. Bandung: Alfabeta Wardaugh, Ronald. (1998), An Introduction to Sociolinguistics. Oxford:Blackwell Publisher Ltd

Widjono Hs. (2007). Bahasa Indonesia Mata Kuliah Pengembangan Kepribadian di Perguruan Tinggi. Jakarta: Grasindo. 